\title{
Long Noncoding RNA LINC00460 Facilitates Colorectal Cancer Progression by Negatively Regulating miR-6 I3 [Corrigendum]
}

Wang L, Chen X, Sun X, Suo J. Onco Targets Ther. 2020:13:7555-7569

The authors have advised Figure 6E on page 7565 is incorrect. Due to an error at the time of figure assembly one of the images from $6 \mathrm{G}$ was used as a placeholder and not replaced later. The correct Figure 6 is shown below:

\section{A \\ C}
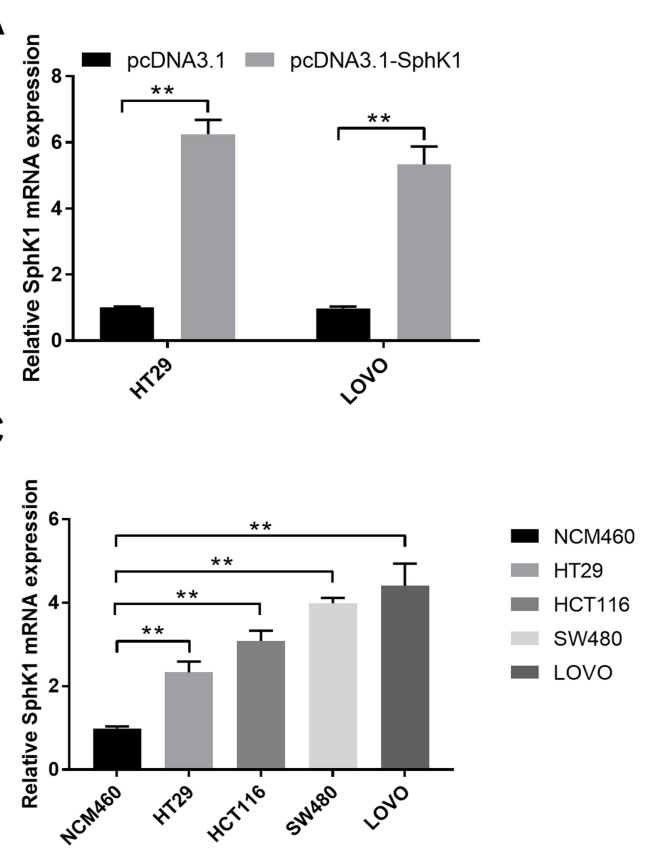

E

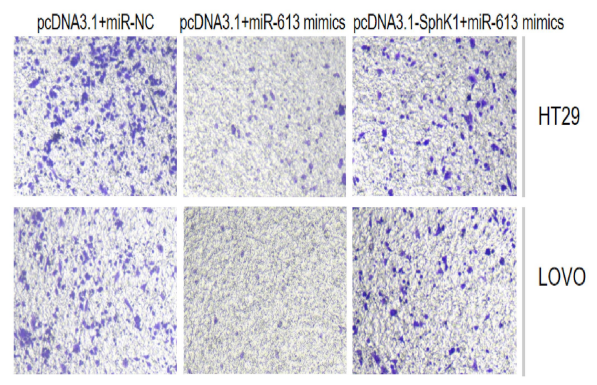

B

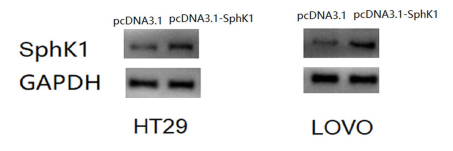

D
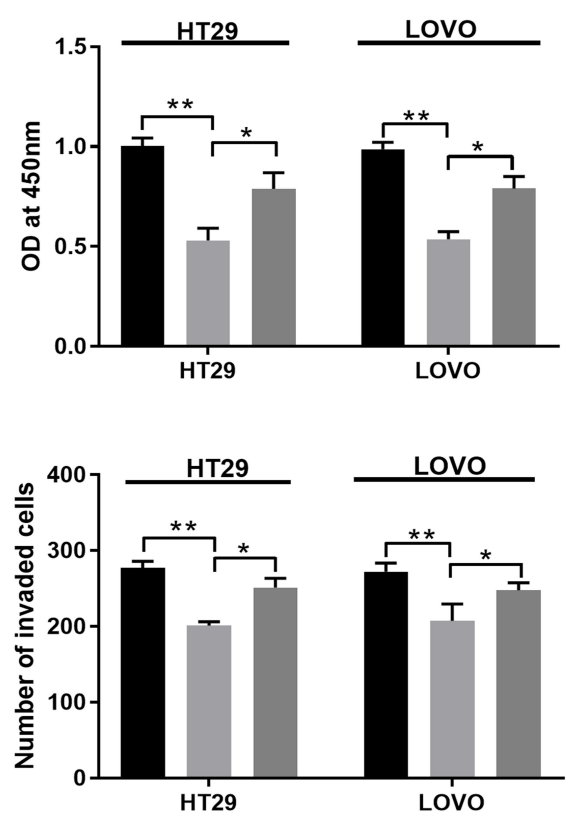

Figure 6 (continued) 
$\mathbf{F}$

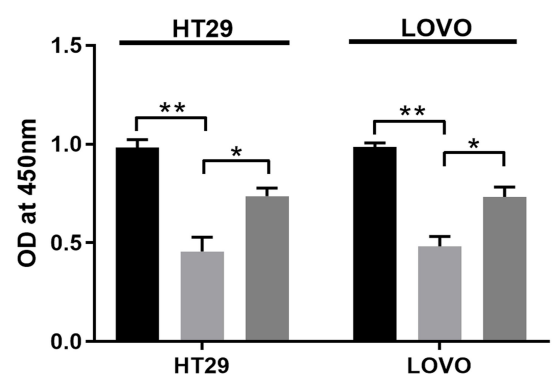

G

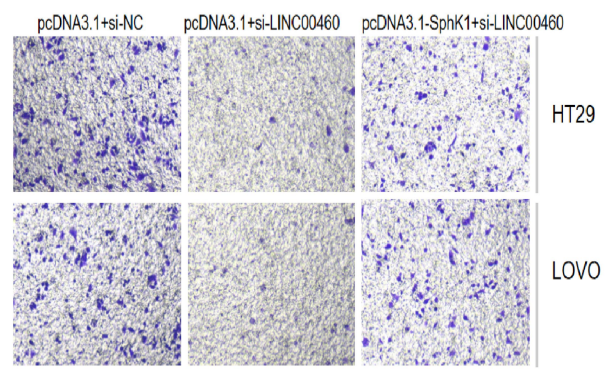

Figure 6

The authors apologize for this error and advise it does not affect the results of the paper.

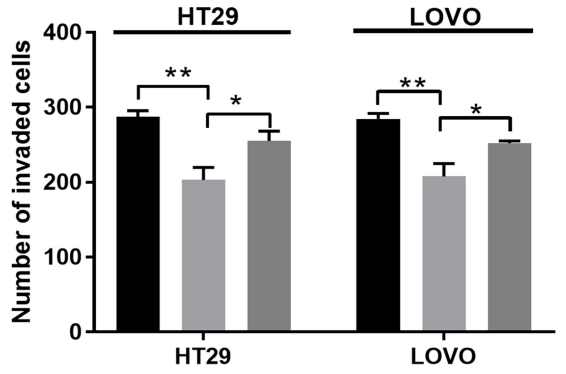

\section{Publish your work in this journal}

OncoTargets and Therapy is an international, peer-reviewed, open access journal focusing on the pathological basis of all cancers, potential targets for therapy and treatment protocols employed to improve the management of cancer patients. The journal also focuses on the impact of management programs and new therapeutic agents and protocols on patient perspectives such as quality of life, adherence and satisfaction. The manuscript management system is completely online and includes a very quick and fair peer-review system, which is all easy to use. Visit http://www.dovepress.com/ testimonials.php to read real quotes from published authors. 